\title{
AOR
}

Selected Papers of \#AoIR2018:

The $19^{\text {th }}$ Annual Conference of the

Association of Internet Researchers

Montréal, Canada / 10-13 October 2018

\section{Mass Media and the Legitimation of Internet Control in Russia: The Case of Telegram}

Mariëlle Wijermars, University of Helsinki

In today's hyperconnected world, states are confronted with the global challenge of responding to potentially disruptive online communications, such as terrorist propaganda and fake news. Formulating effective internet regulation to address these threats carries the risk of infringing upon media freedom and constitutional rights. In the case of Russia, ostensibly sound legitimations have been instrumentalised to bring about a dramatic decline in internet freedom, leading Human Rights Watch (2017: 1) to conclude, that "[s]tate intrusion in media affairs has reached a level not seen in Russia since the fall of the Soviet Union." Up until 2011, when thousands of Russians, mobilised through social media, protested against electoral fraud, the internet remained relatively free. Whereas traditional media were brought under increasingly strict state control after 2000, channelling unwanted discourses online long relied on active participation in and manipulation of these discourses (Deibert \& Rohoyzinski 2010; Stähle \& Wijermars 2014). Now, the Russian government turned to legal measures, including website blocking, to control the online sphere. A similar backlash could be observed elsewhere, e.g. following the Arab spring. With the 2018 Russian presidential elections approaching and mass street protests, this time mobilised through YouTube, re-emerging in the spring of 2017, efforts to control online communications are intensifying.

Controlling public opinion may well be decisive for Russia's "success" in expanding its system of internet controls without arousing popular resistance. Scholarship thus far, however, has neglected to critically examine how the Russian government legitimates and cultivates popular support for restricting online freedom of speech. This paper aims to address this crucial aspect of internet censorship by studying how restrictions of internet freedom, freedom of expression and the right to information and privacy are framed in political and media discourses. Employing a mixed methods, case-study approach, it analyses how frames are produced by policymakers and how they are translated and disseminated in state and (semi-)independent media. Examining the framing of legislation as it passes through these levels of communications can increase our understanding of why, up until now, resistance to these restrictions has been marginal. Russia's expansion of internet controls and surveillance prerogatives and their legitimation are not unique, nor are they an exclusive feature of hybrid and authoritarian

Suggested Citation (APA): Wijermars M. (2018, October 10-13). Mass Media and the Legitimation of Internet Control in Russia: The Case of Telegram. Paper presented at AolR 2018: The 19th Annual Conference of the Association of Internet Researchers. Montréal, Canada: AolR. Retrieved from http://spir.aoir.org. 
regimes. Similar tendencies can be noticed elsewhere in Europe, where anti-terrorism measures, neoconservative tendencies (e.g., presumed societal values concerning sexuality), as well as policies aimed to protect children put pressure on media freedom and freedom of expression (Nieminen et al 2015). The research aims to contribute to this urgent debate on balancing citizen protection with the safeguarding of democratic principles.

A critical study of these legitimation strategies is warranted since the Russian government invests significant efforts in presenting its policies as reasonable and necessary, and claims to act in response to popular demands for regulating the internet. For example, in 2017 , a proposed law regulating social media supposedly responded to societal concerns about online 'death groups' inciting teenagers to commit suicide. Such legitimating frames appear to be successful in maintaining a high level of support for internet censorship. According to independent pollster Levada Center, 60 percent of respondents were in favour of restricting online communications in October 2016 (Konobeevskaia 2016). Only a third of respondents thought website blocking could be used against civil activists (Levada Center 2016). In a more recent poll, connected to a proposal to introduce an age-limit for social media use, 62 percent supported the initiative (VTsIOM 2017).

The legitimation of censorship largely relies on portraying the internet as a dangerous information space; posing a threat to state security, stability, shared moral values and individual safety. It relies on the illusion of creating an online safe space and the presentation of "control as freedom" (Chun 2006: 274). The paper, therefore, investigates the affective dimension in frame building: the extent to which the restriction of civil rights is legitimated through mobilising sentiments of anxiety, distrust and fear. How is internet control, including surveillance and banning of online anonymity, reconceptualised into a virtue of effective state governance, rather than a violation of democratic rights? Affective framing may be particularly persuasive among audiences with limited understanding of information technologies. How do framing strategies play into feelings of vulnerability and sense of incapacity to control perceived dangers inherent to online communications?

\section{Methodology}

The paper presents a case study examining the legitimation of user data storage, surveillance and restriction of online anonymity, on the example of messaging application Telegram. To justify legal measures in these domains, policymakers have framed their proposals as anti-terrorist, or claimed the need to protect personal data from foreign states. Typically, anonymity and privacy are recast as secrecy indicating criminal (e.g., drug dealers) or morally derogatory intent (e.g., paedophilia). The research draws upon the fields of political communication, internet governance and media studies. It primarily employs discourse analysis (in particular frame analysis) complemented by content and legal analysis. In Russia, television continues to be the leading source of information, overtaken by the internet only among the younger generation (Khruleva 2017). Television is, on average, perceived to be a more reliable information source than the internet (Levada Center 2016). The paper, therefore, diverts particular attention to television news and popular genres such as talk shows. 


\section{References}

Stähle, H., and M. Wijermars. 2014. "Forget Memory. Aleksei Navalnyi's LiveJournal and the Memory Discourse of the Protest Movement (2011-2012)." Studies in Russian, Eurasian and Central European New Media (12): 105-128.

Chun, Wendy Hui Kyong. 2006. Control and Freedom: Power and Paranoia in the Age of Fiber Optics. Cambridge, MA: MIT Press.

Deibert, Ronald, and Rafal Rohozinski. 2010. "Control and Subversion in Russian Cyberspace." In Access Controlled: The Shaping of Power, Rights, and Rule in Cyberspace, edited by Ronald Deibert, John Palfrey, Rafal Rohozinski and Jonathan Zittrain, 15-34. Cambridge, MA \& London: MIT Press.

Human Rights Watch. 2017. Online and On All Fronts: Russia's Assault on Freedom of Expression. July 2017, accessed 15 July 2017, https://www.hrw.org/sites/default/files/report pdf/russiafoe0717 web 1.pdf.

Khruleva, Tat'iana. 2017. "Televizor prodolzhaet lidirovat'." Rosbalt 21 April, accessed 15 July 2017, http://www.rosbalt.ru/russia/2017/04/21/1609456.html.

Konobeevskaia, Nadezhda. 2016. "Rossiiane stali men'she doveriat' televideniiu" [Trust in television has dropped among Russians]. RBC 18 November, accessed 26 April 2017, http://www.rbc.ru/politics/18/11/2016/582dc27f9a794723c3f3a270.

Levada Center. 2016. "Doverie SMI i tsenzura" [Trust in mass media and censorship]. 18 November, accessed 26 April 2017, http://www.levada.ru/2016/11/18/doverie-smi-itsenzural.

Nieminen, Hannu, Allessandro D'Arma, Claudia Padovani and Helena Sousa. 2015. "Challenges and Confusion in Media Regulation. A Four-country Comparison." In European Media in Crisis. Values, Risks and Policies, edited by Josef Trappel, Jeanette Steemers and Barbare Thomass, 163-181. Abingdon and New York: Routledge.

VTsIOM. 2017. "Press-vypusk No. 3347. Zabanit' sotsseti?" 10 April, accessed 15 July 2017, https://wciom.ru/index.php?id=236\&uid=116150. 